\title{
Factors Determining Industrial Competitiveness And The Role Of Spillovers
}

Ewert P.J. Kleynhans, Ph.D., North-West University, South Africa

\begin{abstract}
This article applied regressions and panel data analysis to determine how micro-economic spillovers enhance the competitiveness of firms and industries. What made this study unique was that it considered the interactions between various spillover factors working simultaneously and their effect on competitiveness and also investigated possible harmful effects of spillovers. Data from the Manufacturing Firm Survey of the World Bank was used, which covered the first decade of the third millennium, including world economic crises. The investigation on sales used crosssectional regressions, following a survey conducted on sales and competitiveness. The general findings were that FDI and technological expenses offered little spillover advantages to firms, but that spillovers from research and development do enhance competitiveness. Managerial expertise and education of the workforce restrict spillovers and enhance competitiveness, while a larger and less educated workforce increases leakages of information and spillovers, suppressing competitiveness. The results further revealed that exports and spending on communication, machinery and equipment, a trained work force and innovation all enhanced sales, but the numbers of new firms and the number of privately owned businesses suppress competitiveness. Concerning the negative effects of spillovers, corruption, crime, theft and disorder increase spillovers and curb competitiveness. More spending on security decreases these negative spillovers, as does support from well-known suppliers. A larger workforce causes more negative spillovers, as do the number of new and temporary workers, more competitors and new suppliers. The findings of this study will be of special value to managers and project planners.
\end{abstract}

Keywords: Production; Manufacturing; Spillovers; Technology; R\&D; FDI; Industrial Development; Competitiveness; Clusters; Information; Agglomeration; Efficiency

\section{INTRODUCTION}

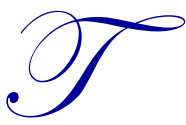

his study examines factors that influence the economic competitiveness of firms and industries, with a special emphasis on the role of spillovers during the micro-economic production process. Much literature exists on factors that determine competitiveness of firms and industries and the determining factors are well known. There are input factors, which are determined by suppliers, market conditions determining demand, supporting factors such as business associations as well as firm structures and rivalry. Michael Porter (1998) modelled his famous Porter Diamond model of competitiveness. This was followed by several new theories and research findings. There is the enhancement of production factors, the classical concepts of absolute advantage, the Malmquist index, the nine-factor model, the generalised double diamond and the duel double diamond, to name but a few (Cho \& Moon, 2005). All these models convey important theoretical advances, but they also note the importance of spillovers - without defining the term or paying much attention to this concept. This paper aims to investigate and measure the effect of spillovers rendering firms and industries internationally competitive.

The concept of spillovers on a micro-economic level is often mentioned in passing, without paying much attention to it. The term is unclear or 'woolly'. By 'woolly', the author means that no-one is certain what it really is or what its effect on the production process is. This study forms part of an on-going research agenda, searching for factors that may enhance the international competitiveness of a country or a region, starting at the firm's production level. Within this context, spillovers can be defined as knowledge, skills and technological capabilities and capacity that firms acquire while they or their employees are in contact with other firms and/or employees. Paul Krugman (1991) 
emphasises that it is firms that compete with each other, and not countries. Enhancing competitiveness should therefore start by making the production processes of firms and industries more efficient and productive.

Data on firm level is not easy to obtain as the South African statistical services (StatsSA) do not publish their firmlevel data in an effort to protect their sources. The World Bank does, however, publish figures from their World Bank surveys on manufacturing firms from time to time. This study utilised their data from 2003 to 2010 , which covers most of the first decade of the third millennium, including the world economic crises. The investigation on the sales made cross-sectional regressions, following a survey done by the researcher during 2011 regarding sales and competitiveness, which also includes some data from the World Bank's Enterprise Survey of 2011.

This paper follows the following structure. In the first section, the emphasis is on the theoretical aspects that determine competitiveness and spillovers. This will be followed by a literature study, highlighting existing research findings, which will support the current study and indicate the need for the current study. Then the empirical results, as well as the research findings will be provided. The article will conclude with a summary, conclusion and some recommendations.

\section{THEORETICAL ASPECTS}

Porter's Diamond of Competitiveness states that competitiveness depends on four main factors (Porter, 1998). These are input supply factors, market demand, firm structure, strategy and rivalry, and finally firms that are related and provide support, as well as supporting associations. From this model, several developments grew and other models were developed. The most important contribution of these factors and models is their operation on the microeconomic level.

The traditional micro-economic theory of the firm, operating under perfect competition, depicts an equilibrium position where supply equals demand at the point where marginal income equals marginal costs. This occurs at the point where the market price equals marginal costs. If the various cost functions could be pressed down, the marginal cost curve would intersect the price line to the right, delivering more goods at the same price - or in effect be able to produce the same quantity at a lower price. The most important effort to enhance competitiveness would then be to produce more with lower cost structures. Firm structure and production efficiency should be organised in such a way that firms could produce goods of the same or better quality at lower prices. This would increase sales and profits, leading to industrial growth (Kleynhans \& Swart, 2012). On a larger scale, this would lead to industrial growth and the creation of employment, which countries in less developed regions need.

Ideally, more efficient production would be most profitable in the section of the production function where increasing returns to scale exist. This is not possible in the long run, but the ideal situation is to remain in that section for as long as possible, before decreasing returns to scale occur. It is assumed that more developed industries achieve this situation for far longer periods than the less developed, making it difficult for the latter to compete internationally.

Capital investment is of special importance. In order to enjoy continued growth, some profits should be reinvested or additional investments should be found. Capital investment increases a company's ability to raise production levels in a sustainable manner. After new capital stock is paid for, the only existing costs are towards depreciation and maintenance; thereby adding profit, with only limited additional input.

The effective application of new capital investments also embodies spillovers, which leads to greater economic growth. Various economic theories and models emphasise that spillovers from capital investment may increase innovations and flexibility (Perkins, Radelet, \& Lindauer, 2006:110). New and different technology emphasises innovation. Investment in capital goods, such as machinery, patents and the training of employees, could affect their flexibility and innovation during production. This may facilitate streamlined adaptation of better technology and production processes. This could improve economic growth and industrial productivity (Morrison Paul, 2002:292).

Knowledge spillovers promote productivity. It motivates innovation efforts and increases firm competitiveness. Information can be transmitted through human and physical capital and communication technology, if firms have 
the ability and logistics to access and use this new knowledge. Here, the easy transferral and absorption of new knowledge are important. Like Porter (1998), Fedderke and Simbanegavi (2008:22) state that competitiveness depends on the available factors of production, and contacts with other firms and industries, such as suppliers, the authorities, as well as strategies that enable access towards international markets. Knowledge spillovers will, however, only provide a competitive edge as long as it is difficult to copy, of value to producers and not easy to obtain (Ding \& Huang, 2010:950).

Together with Porter's traditional factors, new theories emphasise the value of agglomeration, industrial clusters, international variables and economic geography, which all interact and give special dynamics to the entire system (Cho et al., 2005). Where industries are located in industrial districts, either physical or virtual, producers enjoy the advantages associated with spatial linkages. In close proximity, firms learn from each other and assist each other. They can utilise the services and assistance of related and supporting firms, making firms and industries more efficient and in the end more productive (see Marshall, 1890; Porter, 1998; Krugman, 1991; Kleynhans \& Drewes, 2008). Fedderke et al. (2008:138) found that the South African market possesses a high degree of specialisation and is extremely concentrated.

In this regard, there can be spillovers that occur horizontally between different levels, or vertically, where the advantages of spillovers occur at the same level. Sectoral industrial spillovers can enhance production efficiency as all channels affect each other (Pradeep \& Jong-Rong, 2012:12). Innovation that originated at the original level of production may also be transmitted higher up in the firm.

Research has shown that where firms produce and supply the same goods or services in close proximity, the profits of all firms are higher (Porter, 1998). Research by Ellison, Glaeser and Kerr (2010:1195) also confirmed this. Firms are then forced to be more innovative, but also learn from each other. Porter spillovers then lead to output that is even higher than the mere summation of individual outputs would have been. Proximity, cooperation and rivalry all play their part in intensifying technological and knowledge spillovers, which ultimately leads to higher levels of competitiveness.

To a large extent, globalisation makes location less important, reducing the importance of spatial spillovers (Morrison Paul, 2002:295). Regions in close proximity can, however, also lead to more spatial linkages through networks with suppliers, customers and other contacts worldwide, adding to local competitiveness. An external operating environment promotes productivity (Syverson, 2011:326). Entities in association with globalisation can enhance information technology, which promotes production and decision-making.

Information spillovers rely on human and physical skills and resources. The communicating abilities and logistic support enable firms and industries to attain effective processes, store information and diffuse relevant knowledge and technology. On a regional level, complementary information enhances exchange and innovation. Such spillovers increase innovative efforts and ultimately lead to higher economic growth and development.

On a national level, knowledge spillovers can be country wide or firm specific. The level of proficiency does, however, depend on the quality of the region's human capital and technological ability (Ekholm \& Hakkala, 2007). To enjoy all the spillovers that the developed economies offer necessitates firms and industries to have the absorptive capacity to take advantage of these spillovers (Motohashi \& Yuan, 2010:791). Modern equipment can enhance efficiency and competitiveness; however, if the region does not possess the absorptive capacity, these gains will not be realised. Producing high value-added high technology goods renders the highest profits and sometimes even increasing returns to scale, but this constantly commands new ideas and innovations.

Competitiveness may especially be enhanced through international contacts, which may include international trade, foreign direct investment to facilitate research, and the transfer of modern technology (Cabrer-Borràs \& SerranoDomingo, 2007:1359). Cypher and Dietz (2009:469) also emphasise the advantages yielded through the diffusion of international knowledge from exports. The largest gains in growth can originate from national economic integration. International knowledge diffusion and channels to guide such diffusion can enhance competitiveness if cooperation or at least some contact exits. The following section discusses existing research findings published in current literature. 


\section{THE VALUE AND ROLE OF SPILLOVERS}

This section examines the findings of other researchers on spillovers and competitiveness to assist the current investigation and indicate why the study is necessary. The current study commenced following the work of Dr Elisa Guliani. She conducted research on spillovers in the wine industry of Brazil. The region only has a small group of firms and that enabled her to study the whole industry and to investigate the interactions between these firms, with an emphasis on spillovers that enhanced their competitiveness.

Previous studies have often focused on the spillover effects that occur due to a single factor (e.g. Bernstein \& Nadiri, 1988; Steurs, 1995; Aitken \& Harrison, 1999; Blomstrom \& Sjoholm, 1999; Konings, 2001; Cassiman \& Veugelers, 2002; Ekholm et al., 2007, Fedderke et al., 2008; Hausknecht \& Holwerda, 2013). The current study differs in that regard in the sense that it takes the effect of several factors simultaneously into consideration, leading to interaction and dynamics not found in previous studies, as various factors have an influence on each other.

As globalisation increases, spillovers become more international and firms can reap the advantages everywhere. Holod and Reed (2004:289) found that as information and computer technology develops, linkages between firms, and their suppliers and customers, increase everywhere. Giuliani and Bell (2005:48) as well as Zámborský (2012:464) confirmed this and found that knowledge spillovers even occur across international borders.

Globalisation has increased competition between manufacturers, which is good for both economic development and for consumers; but this also puts pressure on local producers. Some may even be forced out of the industry if they cannot compete with the lower prices of foreign firms. Modern technology can even enable firms to achieve increasing returns to scale, higher efficiency and more profits. More funds are invested in human resources, and research and development (R\&D), and this makes workers competitive internationally (Mostert, 2003).

Existing literature indicates that researchers have found strong links between spillovers and growth in several studies (Salomon \& Jin, 2008:132). Qian and Acs (2013:185) found that newly obtained knowledge enables entrepreneurs to discover more opportunities and applications (Kleynhans \& Zwedala, 2012). New investments may enhance the capacity of firms and their human capital to produce more efficiently, while other firms that are in proximity also reap similar advantages from them (Berthelemy, 1995).

These transfers may also enhance the productive capacity of other firms in the vicinity (Kleynhans \& Zwedala, 2012). Through various linkages, growth in one sector usually has a ripple effect, also benefiting others firms and industries (Clemes, Arifa \& Gani, 2003). Lasch, Robert and Le Roy (2013:671) also found knowledge spillovers being enjoyed by new firms in the information and technology industry. The flow of information between different firms can increase production efficiency and this may improve a firm's competitive position. Kleynhans and Zwedala (2012:344) found that engineers regard the sharing of knowledge to be important. It eases the task of engineers and enhances productivity.

Efficiency and competitiveness enhancing spillovers may have an effect on the industrial development of a region or country (Drucker, 2011). Spillovers from foreign direct investment may accompany such investments. Knowledge spillovers that flow from research and development $(\mathrm{R} \& \mathrm{D})$ may lead to better indigenous technology, while improved human capital could improve productivity. The use of skilled engineers and superior equipment by one firm or industry can cause technology spillovers between them, as companies come into contact with one another.

Innovative activities lead to competitive gains and produce spinoffs, which other firms can utilise as spillovers. It is, however, mostly those firms that innovate themselves who are in the best position to enjoy such spillovers from others (Bernstein et al., 1988). This also stresses the value of R\&D. Firms that conduct much R\&D also produce many spillovers. These firms and others in their vicinity will enjoy lower cost structures in their production processes and receive the most gains and profits (Steurs, 1995). This makes firms more competitive and also spills down to lower prices, rendering consumer surpluses to the community. Audretsch, Hülsbeck and Lehmann (2012:587) also found that spillovers from university research and the competitiveness of regions are complementary in the formation of innovation and an entrepreneurial climate. 
In the available literature on industrial development and industrial organisation, some researchers apply mathematical analysis to investigate the productivity, technical progress and scale efficiency of the manufacturing industries. Kleynhans and Pradeep (2013) used methods of data envelopment analysis (DEA) and the Malmquist productivity-change index to evaluate the effects of the industrial reform policies of India. Other mathematical approaches may employ Cobb-Douglas production functions, or calculate horizontal and vertical spillovers.

Firms in industrial districts, networks or clusters benefit more from knowledge sharing spillovers than those operating in isolation (Cabrer-Borrás et al., 2007:1368). Agglomeration also offers a pool of skilled labour that benefits firms. Workers come into contact with each other and learn from one another, leading to information, knowledge and technological spillovers (Marshall, 1890:272; Krugman, 1991:484).

Spatial spillovers across geographical space enhance competitiveness (Cho et al., 2005). Where firms are in close proximity, such as in the same industrial district, province or region, there is a greater possibility that they might collaborate in innovative activities. Regional spillovers increase local innovation and eventually promote local and regional economic growth. There exists a complementary information exchange between industries yielding higher returns on innovation efforts (Cabrer-Borrás et al., 2007:1359).

Kleynhans et al. (2008:2) found that locations where similar industries share customers and suppliers among firms, production efficiency is higher due to agglomeration advantages, such as the availability of skilled labour and emanating technology spillovers. Zámborský (2012:464) also found that spillovers at clusters benefit firms.

This also emphasises the value of investment in training, because an adequate pool of skilled labour is essential for firms and industries to develop competitiveness (Cabrer-Borrás et al., 2007:1357). The promotion of the human capital base deserves special attention because it offers productive workers able to innovate and promote the competitiveness of firms (Alvarez, 2007:377).

Spillovers can also enhance the absorptive capacity of an industry or country. This forms a kind of tautological loop, as those with better absorptive capacity can more easily enjoy the strategic advantage of spillovers, which may enhance their competitive position (Giuliani et al., 2005:48). Through time, spillovers also leak to other firms, which improves their absorptive capacity and eventually the absorptive capacity of the whole country will increase, favouring all.

Jain (2013) found that knowledge builds innovative capability. Jain suggests that knowledge in various locations may complement each other. There might be constraints that limit external knowledge formation, but such constraints might also increase innovative performance (Garriga, Von Krogh \& Spaeth, 2013). Askenazy, Cahn and Irac (2013:293) discovered that the relation between innovation and competition is of a U-shape. In close proximity of the technological frontier, profits from innovations are high, as there is less competition there; however, if there is too much competition, this might also lead to a decline in innovation. The curve turns inelastic as the costs of R\&D rise, up to the point where it collapses altogether. The smaller the firm, the more likely this is, as the curve will become all the more flat or inelastic.

International contact through multinational enterprises, for example, can be a source of knowledge spillovers. Alvarez (2007:377) found that this also assists firms in becoming exporters, but his research could not confirm the concept of "learning by exporting". Research by Salomon and Jin (2010) did, however, find a relation between exports and learning, but they found that those that are more competent in the application of technology enjoyed more advantages from this learning process, because they are in a better position to take advantage, since they are better equipped to transform the acquired expertise into new innovations. Cabrer-Borrás et al. (2007:1366) found that importers also contribute positively to regional innovative efforts, but not as much as the domestic R\&D efforts of the region itself.

FDI can increase exports and create employment. It may lead to spillovers from new R\&D, teach new activities and conduct between firms and business partners, while also training the workforce (Motohashi \& Yuan, 2010:790). He and Maskus (2012:279) found that spillovers that are most likely to lead to innovation are those found locally, while FDI often assists in the development of these new innovations into new products. On a micro-level, Blomstrom et al. 
(1999) found that FDI led to positive spillovers in Indonesia, but other researchers found conflicting results. Most studies found no further spillover linkages to other firms, except for those who received the original investment (e.g. He \& Maskus, 2012; Aitken \& Harrison, 1999; Cho et al., 2005; Konings, 2001; Motohashi et al., 2010; Zámborský, 2012). Aitken et al. (1999), for example, found no evidence that domestic firms benefit from FDI spillovers in Venezuela. Konings (2001) also found positive advantages for firms receiving FDI, but found that locally-owned firms often suffer. Receiving countries can benefit from knowledge flowing from abroad through FDIs and MNEs (Kesidou \& Romijn, 2008). Local firms and industries might, however, miss the benefits of spillovers if the gap between the technological base, locally and abroad, is too prominent and their absorptive capacity is limited (Konings, 2001).

A special advantage of modern technology is its flexibility within firms (Morrison Paul, 2002). It can be applied to various situations and production processes. Konings (2001) found that it can offer positive spillovers, enhancing the productivity and profits of local firms, but it could also put too much pressure on local firms due to the higher competition effect. This and other adverse effects on firms and industries through spillovers deserve special attention and are discussed in the following section.

\section{THE NEGATIVE EFFECTS OF SPILLOVERS}

As spillovers enhance production in many ways, it leads to the assumption that production spillovers are always benefiting firms. The fact of the matter is, however, that spillovers may also have negative and even harmful effects on production. Firms in close proximity enjoy spillover advantages, but firms should protect information of value. Spillovers often enable unwanted externalities. Innovation ownership and intellectual property should be protected and, if possible, patents can assist (Varian, 1992:435).

In many cases, it might be to the disadvantage of firms if competitors gain their special information or knowledge. Specific expertise and intellectual property are often protected. That is also the reason why a firm that possesses a new discovery usually seeks patent rights. This protects the firm against others and also in some sense provides a firm with a kind of monopoly. Industrial espionage occurs all the time. This is also the reason why several governments' intelligence agencies have special anti-industrial espionage divisions. It is therefore also important to note the harmful effects that production spillovers might have.

Firms try to protect their privileged knowledge and control information flows (Cassiman et al., 2002). Firms and universities can profit from mutual synergy that joint research ventures offer. While firms can provide financing, universities have the knowledge and skilled manpower. Firms find it advantageous to link with universities, as this may render access to free advice (Giuliani et al., 2009). This might, however, also lead towards a free-rider problem, as firms take advantage of the investments of others. Audretsch et al. (2012:587) do, however, suggest that R\&D by universities might also lead to crowding-out effects (Kleynhans \& Zwedala, 2012). These aspects deserve more attention, which emphasises the importance of the current research.

Bennett et al. (2013) found that competition among firms may lead to corrupt or unethical activities by firms. They may violate government regulations with regard to price control, pollution and entry strategies, especially where inspection leniency exists. The following section explains the methodology followed by the current study.

\section{DATA AND METHODOLOGY}

This study applied regression analysis and panel data estimates. The necessary econometric tests, such as multicollinearity, serial correlation, heteroskedasticity, co-integration, etc. were performed on the estimations of the various models to ensure that these were in order and enhancements were made where necessary.

A pilot survey was initially conducted at manufacturing firms in the North West Province and Gauteng in South Africa. This gave some insight into the way that firms organise their production and what their perceptions regarding spillovers are. These results were not from a large enough sample to generalise, and not taken scientifically random. It did, however, provide some insight into the research topic and assisted in the interpretation of the final analysis. 
Most data from the empirical study were then obtained from the enterprise surveys conducted by the World Bank. The sample used included 1057 firms. Data of the various firms are taken as a whole sample without distinction between various industries. If a specific data item was missing, those firms were excluded from that particular regression. For that reason, the sample size varies between the various topics investigated. The research with regard to spillovers and sales conducted cross-sectional regressions, utilising a survey of 276 randomly chosen firms done by the researcher during 2011. Some data were also taken from the World Bank's Enterprise Survey of 2011.

The databank and other available data from sources, such as Statistics South Africa and the South African Reserve Bank, were not always perfectly suitable for the intended study, forcing the researchers to use proxies and to aggregate some data series. As a direct measure for spillovers does not exist, the number of competitors and sales were used. Firms have to respond to the activities of others to stay competitive and the more firms in an industry there are, the stronger the competition will be. To increase sales and profits, firms have to be competitive.

The influence of spillovers on the competitiveness of firms was first investigated. The effects of technology, research and development (R\&D), and direct foreign investments (FDI) were taken simultaneously. This not only illustrates its spillover effects on competitiveness, but also the relationships and interactions between these variables. A large share of foreign ownership was regarded as a measure of FDI, and investment in technology was measured by the level of IT expenditure. Spillover estimates are often criticised because of the problem of endogeneity. The simultaneous inclusion of parameters for $\mathrm{R} \& \mathrm{D}$, exports and time lags into the regression analysis addressed this problem to some extent.

Foreign licensing, training costs, utilisation capacity, and the certification of international quality were used to represent $R \& D$. The efficiency of firms to invest in R\&D and its ability to use its capacity were indicated by the capacity utilisation variable. Foreign licensing from abroad and the certification in line with international quality were taken as dummies. International quality certification implies that a firm's products are internationally exportable and accepted in other countries, implying that the firm is competitive.

Following this, the influence of human capital on spillovers was estimated. Cypher et al. (2009) regard research and development as a measure of human capital investment. Money spent on the training of workers is seen as human capital investment. Better training of a region's human capital increases workers' ability to absorb new technology and processes and take more advantage from spillovers. It should also be noted that the cost of training workers also depends on the absorption capacity of an industry, region or country.

Parrotta and Pozzoli (2012:167) and Balsvik (2011:285) found that inter-firm labour mobility could facilitate the transfer of knowledge. This may increase the absorption and distribution of knowledge and raise productivity on all levels of the labour force (Kleynhans \& Labuschagne, 2012:6920). Better skilled workers can take advantage of new technology that is constantly introduced. The effect of the number of workers, their level of education, as well as managerial experience on spillovers and competitiveness were all investigated in this study.

The research then studied the effects of various spillover effects on sales. The logarithm of sales was regarded as a proxy for firm growth, productivity and competitiveness. The effect of direct exports, the cost of communication, the number of new competitors in the industry, cost of machinery and equipment, number of skilled production workers, new projects within firms and the percentage of local private ownership were used as independent variables, representing the various kinds of spillovers. Most of these variables were expressed as logs. These were regarded as indicators of knowledge, information and technological spillovers during the process of micro-economic production. The numbers of skilled workers were seen as a measure of education and new projects of a firm regarded as a proxy for innovation.

In the final section of the research, the negative effects of spillovers were studied. Spillovers and their effect on firm growth, competitiveness and industrial development were determined against levels of corruption, crime, theft and disorder, the amounts that firms spend on security, internet communication, the number of employees, including temporary labour, the length of time suppliers are already known to firms, and the use of new suppliers to provide information. The next section reports on the empirical findings of this study. 


\section{EMPIRICAL RESULTS}

\subsection{The Influence on Competitiveness}

In studying the role of spillovers and its influence on competitiveness, most results were as expected and in line with the findings of other researchers; although there were some surprises. The sample size included 1056 firms. The necessary econometric tests were performed and enhancements were made where necessary. An adjusted $\mathrm{R}^{2}$ of $52.6 \%$ indicated that the independent variables explained a reasonable part of variation in the dependent variable. The Prob(F-stat) was zero.

The results of this research are interpreted in Table 1. The effect of FDI should have been positive, increasing competitiveness by enhancing spillovers, but the study revealed that it had very little effect. It seems logical that this investment would be to the advantage of the receiving firm and that others would also gain from it, but this study found that spillovers to other firms are limited. This is also in line with the research findings of other researchers (such as Aitken et al. 1999). If the technological level of local firms was higher and if they possessed better capability to assimilate modern developments, the indirect effects of spillovers from of FDI would have been much higher (Kleynhans \& Zwedala, 2012).

Technological advancement should increase spillovers, but the results did not show this. In fact, the estimate was negative, although very small. As a firm's technological knowledge increases, better ways are found to protect this knowledge, production processes and organisation, which ensures their competitive edge.

Table 1. Spillovers influence on competitiveness

\begin{tabular}{l|l|c|l}
\hline & \multicolumn{1}{|c|}{ Variable } & Spillovers & \\
\hline FDI & Foreign ownership & - Neg. & \\
\hline \multirow{2}{*}{ Technology } & IT Expenditure & - Neg. & $\begin{array}{l}\text { But very small: Techno advancement should } \uparrow \text { spill }- \\
\text { but results do not show }\end{array}$ \\
\hline \multirow{3}{*}{ R\&D } & Capacity Utilisation & + Pos. & \\
\cline { 2 - 4 } & International Quality Certification & + Pos. & Dummy \\
\cline { 2 - 4 } & Foreign licensing & + Pos. & Dummy \\
\cline { 2 - 4 } & Cost of Training Workers & - Neg. & Depends on absorption capacity \\
\hline
\end{tabular}

Source: Author's own estimates

It was found that research and development $(\mathrm{R} \& \mathrm{D})$ leads to spillovers that improve competitiveness, as this causes positive spillovers through foreign licenses, adherence to global standards and higher utilisation of production capacity. Firms that export are in the position to take advantage of spillovers (Salomon et al., 2010).

Exporting firms are in contact with other firms and soon become capable to compete abroad, improve their efficiency, and may also assist other firms if it is in their interest to do so (Kleynhans \& Zwedala, 2012). These firms can easily assimilate the advantages that research and development offers as they possess the ability to enjoy the knowledge spilled over from others they are in contact with on the international front. These firms are also able to restrict the amount of knowledge and technological spillovers that flow towards other firms, which could harm their own ability to compete effectively.

The cost of the training workers had a negative effect on spillovers and competitiveness. It should, however, be emphasised that this also depends on absorption capacity. Some variables negatively affected spillovers. As firms spend more on the training of their employees, they find it easier to protect their sensitive knowledge that they do not wish to share with their competitors. In this way, spillovers are limited as the firm takes better control of their privileged information that improves their expertise and competitiveness. Training yields a workforce that can differentiate between information that is valuable to the firm and information that may be shared with other firms. 


\subsection{The Link between Human Capital and Knowledge Spillovers}

The regressions investigating the relationship between the quality of human capital, spillovers and competitiveness revealed that the competitiveness of firms increase by $1.7 \%$ if managerial experience rises by $1 \%$. When the level of education among the workforce rises by $1 \%$, competitiveness increases by $24.97 \%$ (Kleynhans \& Zwedala, 2012). But then again, if the number of workers increase, the likelihood of spilling information to competing firms increases, which will let their competitiveness drop by $0.04 \%$ for every $1 \%$ increase in the size of the workforce.

The final findings on human capital are interpreted in Table 2. When considering the factors of human capital, it was found that firms with higher levels of managerial experience would guard their intellectual property better; spillovers would be less and the firm would be more competitive. The same applies to the level of education and training of the workforce. A higher level of workers' education leads to competitive increases. More educated workers will limit spillovers, leading to higher competitiveness. On the other hand, when there are more workers in a firm, contact with workers from other firms would increase. People would learn from each other and more information flows between various firms will occur, increasing various knowledge and technological spillovers. This would, however, suppress the individual competitiveness of firms.

Table 2. Spillovers in relation to human capital

\begin{tabular}{l|c|c}
\hline & Spillovers & Competitiveness \\
\hline Managerial experience & $\downarrow$ & $\uparrow$ \\
\hline Worker's level of education & $\downarrow$ & $\uparrow$ \\
\hline Number of employees & $\uparrow$ & $\downarrow$ \\
\hline Source: Author's own estimates & & \\
\hline
\end{tabular}

Source: Author's own estimates

\subsection{Sales as a Proxy for Firm Growth and Competitiveness}

The research then investigated the effects of various factors that have an influence on sales by firms. Sales were used as a proxy for firm growth, productivity and competitiveness. The essential econometric tests and adjustments were performed. In this case, cross-sectional data of 276 firms were used. The $\mathrm{R}^{2}$ was $81 \%$ indicating a good overall fit, while the adjusted $R^{2}$, which is very close to the $R^{2}$, indicates that the number of variables in the model is adequate and the specification correct. The F-statistics indicated that the model as a whole is statistically significant.

What was learned from this research is summarised in Table 3. The empirical analysis revealed a positive relationship between firm growth and direct export, the cost of machinery, equipment and cost of communication, as well as the level of education and innovation. As could be expected, more competitors in the industry would suppress competitiveness. The same negative relationship was also found with regard to the percentage of local private owners. These findings were mostly in line with the findings of previous research reported in the existing literature (see e.g. Hausknecht et al., 2013).

Table 3. Sales as a proxy for firm growth, productivity and competitiveness

\begin{tabular}{l|c}
\hline \multicolumn{1}{c}{ Variable } & Effect \\
\hline Direct export & + Pos. \\
\hline Cost of communication & + Pos. \\
\hline Number of new competitors & - Neg. \\
\hline Cost of machinery and equipment & + Pos. \\
\hline No. of skilled production workers (= edu) & + Pos. \\
\hline New projects by a firm (proxy for Innovation) & + Pos. \\
\hline \% local private ownership & - Neg. \\
\hline
\end{tabular}

Source: Authors' own estimates

\subsection{The Negative Effects of Spillovers}

Spillovers might also have negative effects on competitiveness and this was investigated in this section. Data from 1055 firms were utilised. All the necessary econometric tests and adjustments were made. The $\mathrm{R}^{2}$ was $9 \%$ indicating that the fit is significant; while the F-statistics indicated that the model is also statistically significant as a whole. The 
researchers do feel that this $\mathrm{R}^{2}$ is too low and during further research surveys should be used to discover more variables that are more significant within this context. Being the first of its kind, the results were still regarded as important to report.

Among the negative effects of spillovers, this study found that people who are disloyal to firms do not protect the company's confidential intellectual property. This raises spillovers and therefore also depresses the firm's competitive position. The regressions revealed that this occurs especially in cases where corruption, crime, theft and disorder exist (see Table 4). Where firms spent more on security, spillovers and competitiveness increased; however, this finding was not statistically significant. More internet communication did increase spillovers, and this could suppress competitiveness if it helps a firm's opposition, or could raise competitiveness if the firm could utilise the information, knowledge and technological spillovers to its advantage. Suppliers known to a firm for a long time have usually built a working relationship and trust through the years. This might restrict spillovers, but the results were too insignificant to take note of. Spillovers also rise with the number of workers, especially temporary workers. New suppliers can be a source of information. They usually do not have vested interests yet, and are not loyal to anyone at first. This causes spillovers to increase. The effect thereof was found to be positive, but that is not necessarily always the case.

Table 4. Harmfulness of spillovers

\begin{tabular}{l|c|c}
\hline & Spillovers & Competitiveness / Industrial Development \\
\hline Corruption & $\uparrow$ & $\downarrow$ \\
\hline Crime, theft \& disorder & $\uparrow$ & $\downarrow$ \\
\hline Internet communication & $\uparrow$ & $\uparrow \& \downarrow$ \\
\hline \% Cost of security & $\downarrow$ & $\uparrow$ - not stats significant \\
\hline Years supplier is known & $\downarrow ?$ & $\uparrow-$ small \\
\hline New suppliers as a source of info & $\uparrow$ & $\uparrow$ \\
\hline No. of employees & $\uparrow$ but small \\
\hline No. of temp. workers & $\uparrow-$ small & \\
\hline
\end{tabular}

\section{POLICY RECOMMENDATIONS}

This study offers some policy implications. Regions and governments who wish to enhance the international competitiveness of firms and industries in their regions have several options that may increase spillovers of information, knowledge and technology, making production more efficient, productive and competitive.

They could disseminate information and assist contact between role-players. Initiate R\&D and train the workforce, creating human capital with an absorptive capacity, able to utilise new technology efficiently. Cooperation between firms should be promoted. Seminars, conferences and business associations can all be beneficial in this regard. This is important, but the authorities should guard against cartel formation and the crowding-out of private initiatives. Better functioning firms with high absorptive capacity and capabilities can enjoy spillovers, grow faster and contribute more to industry. Eventually, this will create more jobs, alleviate poverty and create wealth, which is of great importance to developed economies.

Research and development that could enhance innovation and competitiveness on a regional level should be promoted. An innovation policy from government might also be of value. Universities and other research institutions should be involved. This will lead to industrial development promoting everyone's welfare (Motohashi et al., 2010:797). In their development, and especially development processes, firms can be supported in their activities that generate knowledge and skills, which will enlarge their capacity to enjoy more of the benefits from spillovers from elsewhere.

Trade liberalisation and investment in local markets should be encouraged. With the right leadership from government, multinational enterprises (MNEs) can transfer useful knowledge and technology to particularly industries. MNEs can also support local firms in their efforts to expand their ability to assimilate new knowledge and information in their operations, especially manufacturers in the organisation of production processes (Alvarez, 2007:390). Together with this, foreign direct investment should be promoted. Joint knowledge creation efforts and 
ventures with other firms should be promoted. This may enable taking advantages of spillovers and may generate more spillovers (Ding et al., 2010:957). Infrastructure promotion will assist in this and will also promote MNCs and FDI. This will provide a basis on which local industrial development and R\&D can occur.

Endogenous growth models usually assume that these spillovers will materialise by itself, but the research of Acs et al. (2012:289) suggests that this often does not and requires specific efforts. A mechanism should be designed that will ensure that spillovers lead to the creation of new knowledge and skills and that these are channelled to the point of commercialisation of these new ideas and abilities.

Local human capital and managerial expertise should be improved through training in order to create an innovative character and an enabling absorptive capacity. Governments should encourage firms to invest in their human capital and also in innovation and knowledge gaining activities. Training also provides spinoffs that can benefit local and global markets, and this should be promoted through appropriate policies. Firms that are more innovative and have a higher absorptive capacity, attract investment funds better, especially from abroad, which often also leads to further development.

Firms should be assisted in protecting their intellectual property. Patent registration should be made easier and faster, and crime and corruption should be suppressed. Acs and Sanders (2012:801) state that stronger patent protection is necessary. Patents that are protected enable firms to develop new knowledge and methods without fear that others may gain competitiveness on them, using their new inventions. Firms that feel safe to develop their ideas further will generate more innovation and entrepreneurship. It will facilitate the growth of the firms, create more jobs and in that way also generate economic growth of the industry and the country as a whole. Policies should, however, ensure that patent protection does not cause such strong competition and rivalry that it stifles overall growth. This study concludes in the following section with a concise summary.

\section{SUMMARY AND CONCLUSION}

The infuence of micro-economic spillovers on the competitiveness of firms and industries was investigated in this study using regression analysis and panel data. In this study, spillovers are regarded as knowledge, skills and technological capacity and capabilities that manufacturing firms gain from each other when in contact on a microeconomic production level that may enhance their level of competitiveness. Following a theory and literature study on the matter, estimates were undertaken to estimate the effects of the most important factors identified in existing literature. The influence of spillovers was considered in general, followed by a focus on spillovers related to human capital. Thirdly, spillover factors affecting sales were studied and finally the negative effects that spillovers might have on competitiveness and efficiency.

What made this study unique was that it considered the simultaneous interactions between various factors and their effect on competitiveness; it also investigated the possible harmful effects that spillovers might have. Learning from other firms in the area, industrial district or network is generally accepted to be beneficial to firms and industrial development in general; however, if competitors obtain sensitive or special information it might also harm a firm. These effects were also estimated in this study.

The general findings were that FDI and technological expenses offered little spillover advantages to firms, but that research and development does lead to competitiveness enhancing spillovers. The value of technology and research does, however, depend on the absorption capacity of the firm, industry and region. Absorptive capacity depends, however, on the expertise, skills and training of human capital. A well-educated workforce and a high level of managerial expertise will reduce spillovers and enhance competitiveness, while a larger workforce leads to more leakages of information and spillover, suppressing competitiveness.

When sales are used as a proxy for competitiveness, firm growth and productivity, the results indicated that exports and spending on communication, machinery and equipment, a trained workforce and new projects, indicating innovation, all enhanced sales. The numbers of new competitors and the size of private ownership suppress competitiveness. The last factor also highlighted the value of multinational enterprises to industry. 
Estimates on the negative effects of spillovers revealed that corruption, crime, theft and disorder increase spillovers, suppressing competitiveness. Larger spending on security therefore decreases these negative spillovers, as do support of long-known suppliers. A larger workforce leads to an increase in negative spillovers, as does the number of new and temporary workers, and the use of new suppliers with whom a trustworthy relationship has not yet been established.

This study investigated the concept of spillovers, which is often mentioned but seldom well defined. An attempt was made to understand this phenomenon better and to actually measure it. This was applied to the South African manufacturing industry. It was found that information and production spillovers mostly enhance competiveness positively, but that it might also have some negative results, which should be properly managed. This study investigated the effects of spillover factors highlighted by existing literature. The researchers have some reservations about their adequate measuring of spillovers. Further research might be of value to do a new survey of firms, asking managers and engineers directly which spillovers they regard as important and estimate the effects of that. Spillovers are an important aspect with regard to the efficiency, productivity and competitiveness of firms and industries, and deserve much more attention and research.

The role of spillovers to enhance international competitiveness of firms and industries was highlighted in this study. The study concluded with some policy recommendations. It was shown that government can assist key industries and stimulate information and knowledge flows and innovation. The promotion of R\&D, MNEs and FDI are important. The study emphasises local research and development and education to ensure an enabling absorptive capacity. To enjoy all the advantages of spillovers therefore requires a basic level of economic development. If well managed, spillovers can be a valuable way to promote firm-level and industrial competitiveness.

\section{AUTHOR BIOGRAPHY}

Professor Kleynhans is associate professor in economics at the North-West University, South Africa. His research focuses on the competitiveness of firms and industries. He serves as member of the national council of the South African Academy of Science and Arts. He obtained a teacher's diploma, a Further Diploma in Mathematics and Natural Sciences, a degree from the University of South Africa, honours and master's degrees in Economics from the Rand Afrikaans University, both cum laude. He obtained his doctorate $(\mathrm{PhD})$ in Economics at Potchefstroom University during 2003. In 2012 he obtained a Master's degree in Philosophy (M.Phil.) at the same university.

\section{REFERENCES}

Acs, Z.J., Audretsch, D.B., Braunerhjelm, P. \& Carlsson, B. (2012). Growth and entrepreneurship. Small Business Economics, 39(2):289-300.

Acs, Z.J. \& Sanders, M. (2012). Patents, knowledge spillovers, and entrepreneurship. Small Business Economics, 39(4):801-817.

Aitken, B. J. \& Harrison, A. E. (1999). Do domestic firms benefit from direct foreign investment: Evidence from Venezuela. The American Economic Review, 89(3):605-618. Jun.

Alvarez, R. (2007). Explaining export success: firm characteristics and spillover effects. World Development, 35(3):277-393.

Askenazy, P., Cahn, C. \& Irac, D. (2013). Competition, R\&D, and the cost of innovation: evidence for France. Oxford Economic Papers, 65(2):293-311.

Audretsch, D.B., Hülsbeck, M. \& Lehmann, E.E. (2012). Regional competitiveness, university spillovers, and entrepreneurial activity. Small Business Economics, 39(3):587-601.

Balsvik, R. (2011). Is labor mobility a channel for spillovers from multinationals? Evidence from Norwegian manufacturing. Review of Economics and Statistics, 93(1):285-297.

Bennett, V.M., Pierce, L., Jason A., Snyder, J.A. \& Toffel M.W. (2013). Customer-driven misconduct: How competition corrupts business practices. Management Science, 59(8):1725-1742.

Berthelemy, J. (1995). Whither African economies? Organisation for Economic Co-operation and Development. Paris: OECD.

Bernstein, J.I. \& M.I. Nadiri. (1988). Interindustry R\&D spillovers, rates of return, and production in high-tech industries. American Economic Review - AEA Papers and Proceedings, 78(2):429-434, May.

Blomstrom, M. \& Sjoholm, F. (1999). Technology transfer and spillovers: Does local participation with multinationals matter. European Economic Review, 43(4-6):915-923.

Cabrer-Borràs, B. \& Serrano-Domingo, G. (2007). Innovation and R\&D spillover effects in Spanish regions: A spatial approach. Research Policy, 36:1357-1371. 
Cassiman, B. \& Veugelers, R. (2002). R\&D cooperation and spillovers: Some empirical evidence from Belgium. American Economic Review, 92(4):1169-1184. Jul.

Cho, D. \& Moon, H. (2005). From Adam Smith to Michael Porter, Evolution of competitiveness theory. Singapore: World Scientific.

Clemes, M. D., Arifa, A. \& Gani, A. (2003). An empirical investigation of the spillover effects of services and manufacturing sectors in Asean countries. Asia-Pacific Development Journal, 10(2):29-40.

Cypher, J. M. \& Dietz, J.L. (2009). The process of economic development, Abingdon: Routledge.

Ding, X. \& Huang, R. (2010). Effects of knowledge spillover on inter-organisational resource sharing decision in collaborative knowledge creation. European Journal of Operational Research, 201:949-959.

Drucker, J. (2011). Regional industrial structure concentration in the United States: Trends and implications. Economic Geography, 87(4):421-452.

Ekholm, K. \& Hakkala, K. (2007). Location of R\&D and high-tech production by vertically integrated multinationals. The Economic Journal, 117(518):512-543.

Ellison, G., Glaeser, E.L. \& Kerr, W.R. (2010). What causes industry agglomeration? Evidence from coagglomeration patterns. The American Economic Review, 100(3):1195-1213.

Fedderke, J. \& Simbanegavi, W. (2008). South African manufacturing industry structure and its' implications for competition policy. Journal of Development Perspectives, 4(1):134-189.

Garriga, H., Von Krogh, G. \& Spaeth, S. (2013). How constraints and knowledge impact open innovation. Strategic Management Journal, 34(9):1134-1144.

Giuliani, E. \& Bell, M. (2005). The micro-determinants of meso-level learning and innovation: Evidence from a Chilean wine cluster. Research Policy. 34(1):47-68.

Giuliani, E. \& Arza, V. (2009). What drives the formation of 'valuable' university-industry linkages? Insights from the wine industry. Research Policy. 38:906-921.

Hausknecht, J.P. \& Holwerda, J.A. (2013). When does employee turnover matter? Dynamic member configurations, productive capacity, and collective performance. Organization Science, 24(1):210-225.

He, Y. \& Maskus, K.E. (2012). Southern innovation and reverse knowledge spillovers: A dynamic FDI model. International Economic Review. 53(1):279-302.

Holod, D. \& Reed, R.R. (2004). Regional spillovers, economic growth and the effects of economic integration. Economics Letters. 85:35-42.

Jain, A. (2013). Learning by doing and the locus of innovative capability in biotechnology research. Organization Science, 24(6):1683-1700. Dec.

Kesidou, E. \& Romijn, H. (2008). Do local knowledge spillovers matter for development? An empirical study of Uruguay's software cluster. World Development. 36(10):2004-2028.

Kleynhans, E.P.J. \& Drewes, J.E. (2008). The influence of location on the efficiency of manufacturers in South Africa. Town and Regional Planning, 53:1-9.

Kleynhans, E.P.J. \& Labuschagne, R. (2012). The quality of human capital in South Africa: Evidence from a firm survey. African Journal of Business Management. 6(23):6914-6923.

Kleynhans, E.P.J. \& Pradeep, V. (2013). Productivity, technical progress and scale efficiency in Indian manufacturing: Postreform performance. Journal of Economic and Financial Sciences, 6(2):479-495.

Kleynhans, E.P.J. \& Swart, A. (2012). Spillover effects enhancing sales, production and competitiveness of South African manufacturers. African Journal of Business Management. 6(10):3699-3705.

Kleynhans, E.P.J. \& Zwedala, S. (2012). The contribution of FDI, technology and R\&D towards spillovers in industrial development. Managing Global Transitions, 10(4):341-359.

Konings, J. (2001). The effect of direct foreign investment on domestic firms: evidence from firm level panel data in emerging economies. Economics of Transition. 9(3):619-633. Nov.

Krugman, P. (1991). Increasing returns and economic geography. Journal of Political Economy. 99(3):483-499.

Lasch, F.; Robert, F. \& Le Roy, F. (2013). Regional determinants of ICT new firm formation. Small Business Economics. 40(3):671-686.

Marshall, A. (1890). Principles of Economics. London: Macmillan.

Morrison Paul, C.J. (2002). Supply and demand-driven spillovers and productivity growth, Japan and the world economy. Department of Agricultural and Resource Economics, University of California, Davis, CA, USA. Feb. 14: 285-304.

Motohashi, K. \& Yuan, Y. (2010). Productivity impact of technology spillover from multi-nationals to local firms: comparing China's automobile and electronics industries. Research Policy. 39:790-798.

Mostert, J. (2003). The impact of globalization on developing countries. Paper delivered at the ESSA conference 17-19 Sept. at Somerset West.

Parrotta, P. \& Pozzoli, D. (2012). The effect of learning by hiring on productivity. The RAND Journal of Economics. 43(1):167185.

Perkins, D.H., Radelet, S. \& Lindauer, D.L. (2006). Economics of development, New York: W.W. Norton \& Company.

Porter, M.E. (1998). The competitive advantage of nations; with a new introduction. New York: Palgrave. 
Pradeep, V. \& Jong-Rong, C. (2012). Measuring productivity growth, efficiency change and technical progress in small scale firms in India during pre and post-reform periods. Journal of Economic Policy Reform. 2012(1):1-17.

Qian, H. \& Acs, Z.J. (2013). An absorptive capacity theory of knowledge spillover entrepreneurship. Small Business Economics. 40(2):185-197.

Salomon, R. \& Jin, B. (2010). Do leading or lagging firms learn more from exporting? Strategic Management Journal. 31(10):1088-1113.

Salomon, R. \& Jin, B. (2008). Does knowledge spill to leaders or laggards? Exploring industry heterogeneity in learning by exporting. Journal of International Business Studies. 39(1):132-150.

Steurs, G. (1995). Inter-industry R\&D spill-overs. International Journal of Industrial Organisation. 13(2):249-276. Jul.

Syverson, C. (2011). What determines productivity? Journal of Economic Literature. 49(2):326-365.

Varian, H.R. (1992). Microeconomic analysis. London: W.W Norton \& Company.

World Bank (2014). Enterprise surveys databank. Available at: enterprisesurveys@worldbank.org

Zámborský, P. (2012). Emergence of transnational clusters: Evidence from the Slovak automotive industry. Journal for East European Management Studies. 17(4):464-479. 